\title{
THE PERFORMANCE OUTCOMES OF DIMENSIONS OF SUPPLY CHAIN INTEGRATION: A CONCEPTUAL FRAMEWORK
}

\author{
Nikhat Afshan \\ IBS Hyderabad (IFHE), Survey No. 156/157, Dontanapally Village, Shankerpalli, Mandal, \\ Ranga Reddy District, Hyderabad-501504, India \\ E-mail: nikhat.84@gmail.com
}

Received 30 July 2013; accepted 08 October 2013

\begin{abstract}
A systematic review of literature on the relationship between Supply Chain Integration (SCI) and firm performance shows inconsistency in the results. Some of the studies show a direct relationship between SCI and firm performance, while other shows no significant relationship between these constructs. Further, there is a stream of research which proved that the relationship between SCI and performance is mediated through some intermediate performance outcomes. Based on the gaps identified through an extensive literature review, this study proposes that three dimensions of SCI - supplier integration, customer integration and internal integration will lead to different performance outcomes which will further influence financial performance of the firm. Further, a conceptual framework is presented postulating the relationship between constructs of interest.
\end{abstract}

Keywords: Supply Chain Integration, supplier integration, customer integration, internal integration, and financial performance.

JEL Classification: M11- Production Management.

\section{Introduction}

In the past one decade there has been growing consensus concerning the strategic importance of integrating with suppliers, manufacturers and customers (Bowersox, Morash 1989; Barrat 2004; Rosenzweig et al. 2003). With the growing importance of a well integrated supply chain, it has become one of the main focuses of research in the area of supply chain management.

Supply chain integration has been defined by Clancy (1998) as: “ ...attempting to elevate the linkages within each component of the chain, (to facilitate) better decision making (and) to get all the pieces of the chain to interact in a more efficient way (and thus) . . create supply chain visibility (and) identify bottlenecks" (Clancy, cited in Putzger 1998: 55).

Recently Flyn et al. (2010) gave a more holistic definition of supply chain integration as "the degree to which a manufacturer strategically collaborates with its supply chain partners and collaboratively manages intra and inter organizational processes with the goal to achieve effective and efficient flows of products and services, information, money and decisions, to provide maximum value to the customer at low cost and high speed."

Though SCI has been considered as a vital contributor to business performance (Vickery et al. 2003; Frohlich, Westbrooch 2001; Li et al. 2006; Zhao et al. 2002), the research shows inconsistency in its finding about the relationship between SCI and performance. These issues are related to inconsistent definition and operationalization of SCI and performance constructs. The review of literature shows that SCI has been studied as a unidimensional construct (Vickery et al. 2003; Rosenzweig 2003), two dimensional constructs (Stank et al. 2001; Zailani, Rajagopal 2005; Pagell 2004; Stanley, Wisner 2001), and also as a multidimensional construct (Droge et al. 2004; Narasimhan, Kim 2002; Gimenez, Ventura 2005). Flynn et al. (2010) identified three 
dimensions of SCI which are- supplier integration, customer integration and internal integration. The integration of various functional departments within the firm is termed as internal integration while integration with upstream suppliers and downstream with customer together is termed as external integration.

Similar variation can be seen in the measurement of performance constructs also. Some of the authors have related SCI with the operational performance while others have linked it with financial performance. Some of the other studies have shown the relationship between SCI and financial performance through mediating and moderating variables. They argued that SCI does not directly impact firm performance, instead, it provides companies some competitive capabilities which in turn affect its financial performance (Vickery et al. 2003; Rosenzweig et al. 2003).

Hence, it is important to understand the performance outcomes of different dimensions of supply chain integration. Further, the impact of these performance outcomes on financial performance is also an interesting avenue for research. This study reviews the existing literature on the relationship between supply chain integration and performance. Further, a conceptual research model is presented along with research propositions.

\section{Literature review}

Stevens (1989) highlighted the importance of supply chain integration. He stated that providing a high service level to customers without incurring additional cost is possible only when a company has a well integrated supply chain. His seminal work initiated several research in this area. Although the benefits of having an integrated supply chain was well documented after the work of Stevens, it was first empirically tested by Frohlich and Westbrook (2001). They investigated the relationship between supplier integration, customer integration and performance. The result showed that the companies with a higher degree of supplier and customer integration had the largest rate of performance improvement for all performance measure except for return investment.

Vickery et al. (2003) investigated the impact of supply chain integration strategy on customer service and firm performance. The result showed a positive relationship between supply chain integration and customer service, customer service and firm performance. However, when the impact of supply chain integration was tested on firm performance the result was found to be insignificant showing that the relationship between supply chain integration and firm performance is fully mediated through customer service. This important finding gave an indication that supply chain integration impact financial performance indirectly via some immediate performance outcomes. Hence, it was also an answer for the insignificant result between SCI and ROI found in Frohlich, Westbrook study (2001).

Adding to the literature on SCI, Rosenzweig et al. (2003), investigated the mediating role of manufacturing capabilities (quality, flexibility, delivery and cost) between supply chain integration intensity (a proxy variable for SCI) and business performance. The result supported positive relationship between supply chain integration intensity and manufacturing capabilities. Further, the result showed that the relationship between integration intensity and sales growth and customer satisfaction was partially mediated through manufacturing capabilities.

Frohlich (2002) investigated the impact of e-integration (internet enabled supply chain integration) on performance. The study showed that e-integration has a strong positive impact on the e-business performance (measured as percentage of incoming procurement and outgoing finished goods transacted over the internet) and operational performance of the firm. Germain, Iyer (2006) investigated the impact of internal and external integration in the supply chain on logistics performance and financial performance. They also investigated the moderating role of internal integration on the relationship between external integration and logistics performance. The result suggested that internal integration and external integration has a positive impact on logistical performance. Internal integration was found to moderate the relationship between external integration and logistical performance. Further, internal integration and external integration were found to have no direct impact on financial performance but the relationship was mediated through logistical performance.

Lee et al. (2007) investigated the relationship between supply chain linkages (a proxy for supply chain integration) and supply chain performance. The impacts of three dimensions of supply chain linkages namely supplier linkage, customer linkage, internal linkage were investigated on two well known performance indicators of supply chain, namely cost containment and performance reliability, as well as on overall supply chain performance. The study revealed that all three linkages were positively related to overall performance and performance reliability. While supplier and internal linkages were found to have significant positive impact on cost containment performance, the result was found insignificant for customer linkage.

Li et al. (2009) investigated the relationship between IT implementation, supply chain integration and supply chain performance. The result showed that there is no significant relationship between IT implementation and supply chain performance but the relationship is mediated by supply chain integration. Further, when tested, direct significant relationship was found between IT implementation and supply chain integration and between supply chain integration and supply chain performance. This study again 
confirmed the relationship between SCI and supply chain performance.

Prajogo, Olhager (2012), extended the research framework of Li et al. (2009) by incorporating strategic relationships with suppliers as a potential antecedent of IT implementation. To test the link between information flow and material flow in the supply chain, they considered two dimensions of SCI- information integration and logistics integration. Further they added both the technological aspect (information technology) and social aspect (information sharing) of information integration to provide a more comprehensive framework. They argued that while the use of technology in information sharing is important, the frequency, quantity and quality of information being shared also matters. Information integration requires firms to share strategic supply chain information apart from transaction data such as material or product orders. The result suggested that both information sharing and information technology have significant effects on logistics integration. Long term relationships with suppliers have both direct and indirect effects on performance. The indirect effect is via the effect on information integration and logistics integration.

Wong et al. (2011) investigated the moderating role of environmental uncertainty on the relationships between SCI and operational performance. The result suggested that supplier integration, customer integration and internal integration have a positive impact on delivery, production cost, product quality and production flexibility. Further, the result showed that under high environmental uncertainty (EU), internal integration will have greater impact on production cost and product quality, external integration will have greater impact on delivery and production flexibility. However the moderating effect of the EU was not found to be significant on the relationship between customer/supplier integration and product quality and production cost.

Schoenherr, Swink (2012) investigated the impact of supply chain integration strategies on quality, delivery, flexibility and cost performance. The result showed that the relationship between external integration strategy is moderated by the internal integration only for the flexibility and delivery but not for quality and cost performance.

Flynn et al. (2010) investigated the impact of supply chain integration on performance using both the contingency and configuration approach. They investigated how individual dimensions of SCI - supplier integration, customer integration and internal integration relate to operational and business performance of firms as well as how patterns of SCI are related to operational and business performance. Result showed a positive relationship between internal integration and operational performance, customer integration and operational performance and no significant relationship between supplier integration and operational performance. However, for the business performance only internal integration was found to be significant.

Vaart, Donk (2008) carried out a comprehensive review of 33 research papers published after the year 2000 which studied the effect of level of SCI on the performance of firms. He found that most of these studies showed an insignificant relationship. From a critical review of these studies they reasoned that the insignificance of the relationship may be due to non-existence of a direct relationship. This relationship may be mediated by other variables. This conclusion has support from other studies (Vickery et al. 2003; Rosenzweig et al. 2003). They inferred that it is important to relate the level of integration in a single relationship to the performance outcomes of that relationship. For example if integration is between buyer and supplier, the performance should be measured in terms of the aims of these efforts with respect to this particular relationship like reduction in reaction time, need to hold less stocks etc. which would further impact financial performance of the firms.

\section{Performance measures used in SCI literature}

The analysis of performance measures used in supply chain integration literature shows that authors have addressed some dimension of supply chain management performance measures, but not all. Authors have used either operational measures of performance (Dong et al. 2001; Shin et al. 2000), or only financial performance (Benton, Malone 2005; Duffy, Fearne 2004; Jayaram et al. 2004; Narasimhan, Kim 2002; Tan et al. 2002) or only customer service measures (Bagchi, Skjoett-Larsen 2005; Carr, Pearson 2002; Kaufmann, Carter 2006; Ramdas, Spekman 2000; Stank et al. 2001) or time based measures (Droge et al. 2004). Others have used combinations of these performance measures in their studies (Das et al. 2006; Devraj et al. 2007; Frohlich, Westbrook 2001; Li et al. 2006; Prahinski, Benton 2004; Droge et al. 2004).

Further analysis of these performance measures of item levels reveals the difference in measurement of the same construct, hence the lack of consistency. For example, Dong et al. (2001) used three items (inventory cost, outbound transportation cost and production cost) and Lee et al. (2007) used five items (inbound cost, outbound cost, warehousing cost, inventory holding cost and return on net asset) to measure cost based performance. Droge et al. (2004) used two different factors to capture times based operational performances namely time to market (product development time, product introduction time) and time to product (manufacturing lead time, procurement lead time and delivery speed.) using two and three items respectively.

Frohlich, Westbrook (2001) used three measures of performance, which are productivity, non productivity and marketplace performance. The analysis of productivity and 
non productivity construct reveals that they are measured using time based (manufacturing lead time, procurement lead time etc.), cost based (manufacturing cost, overhead cost etc.) and customer service based (customer satisfaction on time delivery etc.) items, eight items were used to measure both the constructs.

Flynn et al. (2010) used two measures of performance namely operational performance and business performance. They also captured an operational performance using eight items which are a combination of time based (on time delivery, quick introduction of new products in the market, quick response to market changes, etc.) and customer service based (high level of customer service) performance measures. Contrary to this, only three items were used to capture operational performance by Frohlich (2002) (delivery time, transaction cost and inventory turnover) and Aryee et al. (2008) (production cycle time, new product time to market and percentage of supplier getting forecast or demand data).

The same inconsistency can be seen in the measurement of financial performance measures. Flynn et al. (2010) used eight items (growth in sales, return on sales, growth in profits etc.), Kannan, Tan (2010) used four items (market share, ROA, customer service level and overall competitive position), Frohlich, Westbrook (2001) used three items (market share, profitability and ROI), Vickery et al. (2003) used three items (ROI, ROA and return on sales) and Rosenzweig et al. (2003) used also used three items (ROA, percentage of revenue from new product and overall customer satisfaction rating) to capture firm performance.

Table 1 presents the summary of supply chain integration research.

\section{Gaps in literature}

The literature review on the relationship between SCI and performance shows that there is a need:

- To identify the immediate of performance outcomes of different dimensions of SCI.

- To examine the relationship between different dimensions of SCI and their immediate performance outcomes.

- To examine the relationship between immediate performance outcomes and the financial performance of the firm.

\section{Proposed research model}

The conceptual model for research has been developed based on the literature review and presented in Fig. 1. The proposed research model is primarily aimed at capturing the immediate performance outcomes of supply chain integration efforts. It takes into account three dimensions of SCI as suggested by Flynn et al. (2010) which are - supplier
Table 1. Summary of supply chain integration research

\begin{tabular}{|c|c|c|}
\hline $\begin{array}{l}\text { Research Focus } \\
\text { and Theme }\end{array}$ & $\begin{array}{l}\text { Types of } \\
\text { Research }\end{array}$ & Contributors \\
\hline $\begin{array}{l}\text { Relationship } \\
\text { between SCI and } \\
\text { firm performance } \\
\text { (Positive } \\
\text { relationship } \\
\text { supported) }\end{array}$ & Empirical & $\begin{array}{l}\text { - Stank et al. 2001a } \\
\text { - Childerhouse, Towill } 2003 \\
\text { - Gimenez, Ventura } 2005 \\
\text { - Koufteros et al. } 2005 \\
\text { - Kulp et al. } 2004 \\
\text { - Droge et al. } 2004 \\
\text { - Wang et al. } 2006 \\
\text { - Li et al. } 2009 \\
\text { - Kannan, Tan } 2010 \\
\text { - Wong et al. } 2011\end{array}$ \\
\hline $\begin{array}{l}\text { Relationship } \\
\text { between SCI and } \\
\text { firm performance } \\
\text { (Positive relation- } \\
\text { ship not supported) }\end{array}$ & Empirical & $\begin{array}{l}\text { - Hertz } 2001 \\
\text { - Stank et al. } 2001 \mathrm{~b} \\
\text { - Vickery et al. } 2003 \\
\text { - Rosenzweig et al. } 2003 \\
\text { - Germain, Iyer } 2006\end{array}$ \\
\hline $\begin{array}{l}\text { Relationship bet- } \\
\text { ween SCI and } \\
\text { firm performance } \\
\text { (Mixed result) }\end{array}$ & Emperical & $\begin{array}{l}\text { - Prajogo, Olhager. } 2012 \\
\text { - Lee et al. } 2007 \\
\text { - Swink et al. } 2007\end{array}$ \\
\hline $\begin{array}{l}\text { Investigation } \\
\text { of mediators in } \\
\text { the relationship } \\
\text { between SCI and } \\
\text { performance }\end{array}$ & Empirical & $\begin{array}{l}\text { - Salvador et al. } 2001 \\
\text { - Rosenzweig et al. } 2003 \\
\text { - Vickery et al. } 2003 \\
\text { - Swink et al. } 2007\end{array}$ \\
\hline $\begin{array}{l}\text { Investigation of } \\
\text { moderators in } \\
\text { the relationship } \\
\text { between SCI and } \\
\text { performance }\end{array}$ & Empirical & $\begin{array}{l}\text { - Narasimhan, Das } 2001 \\
\text { - Narasimhan, Kim } 2002 \\
\text { - Kim } 2006 \\
\text { - Swink et al. } 2007 \\
\text { - Richey et al. } 2009 \\
\text { - Wong et al. } 2011 \\
\text { - Schoenherr, Swink } 2012\end{array}$ \\
\hline \multirow[t]{2}{*}{$\begin{array}{l}\text { Investigation of } \\
\text { antecedents and } \\
\text { barriers to SCI }\end{array}$} & Conceptual & $\begin{array}{l}\text { - Pagell } 2004 \\
\text { - Aryee et al. } 2008 \\
\text { - Zhao et al. } 2008 \\
\end{array}$ \\
\hline & Empirical & $\begin{array}{l}\text { - Richey et al. } 2009 \\
\text { - Vijayasarathy } 2010\end{array}$ \\
\hline
\end{tabular}

integration, customer integration and internal integration. The immediate performance outcome of supplier integration, customer integration and internal integration has been labeled as supplier related performance outcome (SRPO), customer related performance outcome (CRPO) and manufacturing related related performance outcome (MRPO) respectively.

\section{Constructs descriptions and research propositions}

Supplier integration: Supplier integration refers to the degree to which a firm partners with its suppliers to structure their inter-organizational practices, procedures, strategies and behaviors into synchronized and manageable process in order to fulfill customer's requirements at lowest cost (Chen, Paulraj 2004; Stank et al. 2001; Flynn et al. 2010; Zhao et al. 2008). 
Customer Integration: Customer integration refers to the degree to which a firm collaborates with its customers to improve visibility and enable joint planning (Fisher et al. 1994; Wong et al. 2011). Customer integration provides manufacturer better understanding of market expectation and the opportunities and helps in being more responsive to customer needs and requirement (Swink et al. 2007).

Internal Integration: Internal integration refers to the degree to which a manufacturer structures its own organizational strategies, processes and practices into collaborative synchronized processes in order to meet customers' requirement at lowest cost (Zhao et al. 2008; Flynn et al. 2010). Internal integration emphasizes that different departments in an organization should act as an integrated process rather than acting as functional silos.

Supplier Related Performance Outcome (SRPO): Suppliers play a prominent role in the performance of an organization. Poor product quality and late delivery of raw materials coming from suppliers can add significant cost to buyers in terms of inspection, rework and returns etc. Thus, supplier quality, delivery, flexibility and cost performance are the intermediate outcomes of the implementation of an appropriate supply chain strategy (Chen, Paulraj 2004). Hence, this study describes SRPO as the specific performances that can be achieved with a high level of integration with suppliers.

Customer Related Performance Outcome (CRPO): Customers play a prominent role in the performance of an organization. A close collaboration between manufacturers and customers helps in improving the accuracy of demand information which reduces manufacturer's production planning and product design time and inventory obsolescence. Some of the benefits of integrating with customers are lower product development cost, higher quality with fewer defects, fewer engineering changes and shorter time to market and higher responsiveness (Flynn et al. 2010). Hence, this study describes CRPO as the specific performances that can be achieved with a high level of integration with customers.

Manufacturing Related Performance Outcome (CRPO): The integration of information system across different department to share information and formation of cross functional teams helps in product and process improvement.Some of the other benefits of internal integration are reduced manufacturing cost, reduced manufacturing lead time and short new production lead time etc. Hence, this study describes MRPO as the specific performances that can be achieved with a high level of internal integration.

Financial performance: Financial performance measures reflect the assessment of a firm by factors outside of the firm's boundary (Chen, Paulraj 2004). The conventional indicators used to measure financial performance of a firm are- return on investment, return on assets, present value of the firm, market share, and profitability etc.

Based on the research model presented in Fig. 1 following propositions are proposed:

\section{Relationship between supplier integration and performance}

Past researchers observed that integration between manufactures and suppliers positively influences different performance outcomes. Their observations are summarized below.

The development of strong strategic partnership with suppliers helps in facilitating their understanding and anticipation of manufacturer's needs, in order to better meet its changing requirements (Flynn et al. 2010). The exchange of information between suppliers and manufacturers about processes, products, schedules and capabilities helps manufacturers in developing their production plan and producing goods on time leading to improved delivery performance. The information sharing among supply partners provides several logistics benefits (Zhao et al. 2002; Lee et al. 2007) and also agility and flexibility (Swafford et al. 2008). Supplier integration helps in reducing production costs, administrative costs and logistics costs (Handfield, Nichols 1999; Gimenez, Ventura 2005; Devraj et al. 2007) and hence reduces the cost of running the system (Coase 1937). The integration with suppliers promotes cooperation, coordination and joint problem solving routine (Narasimhan, Jayaram 1998) which reduces waste and redundancy of efforts in managing supply chain activities across partner firms (Swink et al. 2007). Integration with suppliers and customers helps in improving time based performance such as product development time, procurement lead time (Droge et al. 2004; Rosenzweig et al. 2003). The involvement of suppliers in early stage of product development engenders quicker product development and introduction time

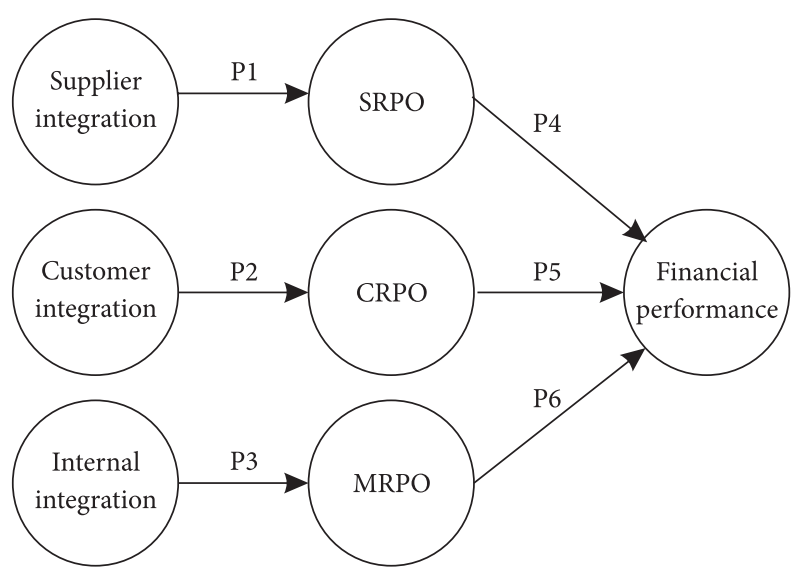

Fig. 1 . The proposed research model 
(Droge et al. 2004). The supplier integration is important to deliver superior value to customers (Ragatz et al. 2002). The close coordination with suppliers is important for reducing delivery lead time and reducing buffer inventories (Handfield 1993). Supplier integration has become critical to success of companies because it helps in significant improvement in terms of delivery quality, shorter cycle time and reduces cost and production lead time (Shin et al.2000; Ragatz et al. 2002). On the basis of the above observation, the following research proposition is proposed:

P1: Supplier integration is positively related to supplier related performance outcome.

\section{Relationship between customer integration and performance}

Past researchers observed that integration between manufactures and customers positively influences different performance outcomes. Their observations are summarized below.

The close relationship between manufacturers and customers helps in improving the accuracy of demand information which helps in reducing the product design and production planning time for manufacturers. The tight integration with customers reduces inventory obsolescence and also costs (Flynn et al. 2010). Customers integration helps manufacturer in becoming more responsive to the need of customers, create greater value and detect demand changes more quickly. Customer integration has been found to impact customer satisfaction, both directly (Homburg, Stock 2004) and indirectly through its relationship to product innovation performance and product quality performance (Koufteros et al. 2005). The manufacturers who are integrated with customers can reduce inventories and decrease delivery times and become more flexible to customer demands, hence make the supply chain more efficient (Barrat 2004; Clark, Lee 2000). On the basis of the above observation, the following research proposition is proposed:

P2: Customer integration is positively related to customer related performance outcome.

\section{Relationship between internal integration and performance}

The importance of internal integration has been widely highlighted in SCI literature. Internal integration have been found have positive impact on operational performance of the firm including logistics performance (Germain, Iyer 2006; Stank et al. 2001) and process efficiency (Saeed et al. 2005). It has also been found to have positive impact on time based performance constructs such as "time-tomarket", "time-to-product" and also achieving high customer resposiveness (Droge et al. 2004). Internal integration has been found to have positive impact on business performance of firm (Flynn et al. 2010). On the basis of the above observation, the following research proposition is proposed:

P3: Internal integration is positively related to manufacturing related performance outcome.

\section{Relationship between SRPO and firm performance, CRPO and firm performance, MRPO and firm performance}

Many studies investigating the relationship between SCI and financial performance have shown that SCI does not directly impact financial performance of the firm, showing that there some intermediate performance outcomes of SCI (Resenzweig et al. 2003; Vickery et al. 2003). Droge et al. (2004) mentioned in their study that managers view quality, cost and inventory improvement as immediate performance outcomes of either types of integration which can further affect financial performance of firm. Hence we argue that immediate performance outcomes of individual dimension of SCI will have positive impact on financial performance of firm. Hence the following research proposition is proposed:

- P4: supplier related performance outcome is positively related to financial performance.

- P5: customer related performance outcome is positively related to financial performance.

- P6: manufacturing related performance outcome is positively related to financial performance.

\section{Discussion}

The above review of literature on the relationship between SCI and performance shows that there are many inconsistencies and contradictions in results. These inconsistencies can be attributed to the way the authors have defined and measured SCI and performance constructs, and, the way this relationship has been tested. Several researchers have also discussed the problem and challenges regarding the definition and measurement of performances in supply chain integration studies (Chow et al. 1994; Vaart et al. 2008; Flynn et al. 2010). Some of the studies have linked the integration of manufacturers with its customers and suppliers with financial performance of the manufacturers (Frohlich et al. 2001; Vickery et al. 2003; Chen et al.; Droge et al. 2004; Jayaram et al. 2004; Kannan, Tan 2005; Narasimhan, Kim 2002; Prahinski, Benton 2004). While other studies have linked supply chain integration to operational performance measures and customer service measures (Gimenez, Ventura 2003, 2005; Humphreys et al. 2004; Li et al. 2006). The inconsistency on the relationship between SCI construct and financial performance indicates that SCI leads to some immediate performance outcomes which in turn impact financial performance. Hence, there is a need to investigate the immediate performance outcome 
of different dimensions of supply chain integration which are- supplier integration, customer integration and internal integration. For instance if a company is well integrated only with its suppliers, their relationship would lead to some performance improvement.However, their performance improvement would be different from a company integrated only with its customers. Similarly, a firm focusing only on internal integration may achieve certain performance improvement which would be different from a firm focusing only on external integration (integration with suppliers and customers).

\section{Conclusion and future research implication}

The main objective of this study was to review the existing literature on relationship between supply chain integration and firm performance. The analysis of supply chain literature shows inconsistency in its finding about relationship between supply chain integration and performance. Based on the gaps identified, this study presents a testable research model postulating the relationship between different dimensions of SCI and their immediate performance outcomes. It argues that supplier integration, customer integration and internal integration would contribute to performance improvement which will be outcome of that particular integration effort. Hence, it proposes three different performance construct resulting specifically from supplier integration, customer integration and internal integration, which would further contribute to financial performance of firm. Hence, this study highlighted that there is a need to:

- Investigate the immediate performance outcome of different dimensions of SCI viz. supplier integration, customer integration and internal integration.

- Investigate how the immediate performance outcomes affects the financial performanceof the firm.

- Test this model in context of emerging economies like India because not much of supply chain integration research has been done in the context of emerging economies.

- The above mentioned issues in SCI literature gives the scope of further research in this area. The development of scales to measure immediate performance outcomes and empirical investigation of the proposed research model in Indian context is our avenue for future research.

\section{References}

Aryee, G.; Naim, M. M.; Lalwani, C. 2008. Supply chain integration using a maturity scale, Journal of Manufacturing Technology Management 19(5): 559-575.

http://dx.doi.org/10.1108/17410380810877258
Bagchi, P. K.; Skjoett-Larsen, T. 2005. Supply chain integration: a European survey, International Journal of Logistics Management 16(2): 275-294.

http://dx.doi.org/10.1108/09574090510634557

Barrat, M. 2004. Understanding the meaning of collaboration in the supply chain, Supply Chain Management: An International Journal 9(1): 30-42.

Benton, W. C.; Malone, M. 2005. The influence of power driven buyer/seller relationships on supply chain satisfaction, Journal of Operations Management 23(1): 1-22.

http://dx.doi.org/10.1016/j.jom.2004.09.002

Bowersox, D. J.; Morash, E. A. 1989. The integration of marketing flows in channels ofdistribution, European Journal of Marketing 23(20): 58-67. http://dx.doi.org/10.1108/EUM0000000000546

Carr, A. S.; Pearson, J. N. 2002. The Impact of purchasing and supplier involvement on strategic purchasing and its impact on firm's performance, International Journal of Operations \& Production Management 22(9): 1032-1053. http://dx.doi.org/10.1108/01443570210440528

Chen, I. J.; Paulraj, A. 2004, Towards a theory of supply chain management: the constructs and measurements, Journal of Operations Management 22(2): 119-150. http://dx.doi.org/10.1016/j.jom.2003.12.007

Childerhouse, P.; Towill, D. R. 2003. Simplified material flow holds the key to supply chain integration, Omega 31(1): 17-27. http://dx.doi.org/10.1016/S0305-0483(02)00062-2

Chow, G.; Heaver, T. D.; Henriksson, L. E. 1994. Logistics performance: definition and measurement, International Journal of Physical Distribution \& Logistics Management 24(1): 17-28. http://dx.doi.org/10.1108/09600039410055981

Clark, T. H.; Lee, H. G. 2000. Performance, interdependence and coordination in business-to-business electronic commerce and supply chain management, Information Technology and Management 1(1-2): 85-105.

http://dx.doi.org/10.1023/A:1019108621684

Costes, F. N.; Jahre, M. 2007. Supply chain integration improves performance: The Emperor's new suit, International Journal of Physical Distribution \& Logistics Management 37(10): 835-855. http://dx.doi.org/10.1108/09600030710848941

Das, A.; Narasimhan, R.; Talluri, S. 2006. Supplier integrationfinding an optimal configuration, Journal of Operations Management 24(5): 563-582. http://dx.doi.org/10.1016/j.jom.2005.09.003

Devaraj, S.; Krajewski, L.; Wei, J. C. 2007. Impact of e-business technologies on operational performance: the role of production information in the supply chain, Journal of Operations Management 25(6): 1199-1216. http://dx.doi.org/10.1016/j.jom.2007.01.002

Dong, Y.; Carter, C. R.; Dresner, M. E. 2001. JIT purchasing and performance: an exploratory analysis of buyer and supplier perspectives, Journal of Operations Management 19(4): 471-483. http://dx.doi.org/10.1016/S0272-6963(00)00066-8

Droge, C.; Jayaram, J.; Vickery, S. K. 2004. The Effects of internal versus external integration practices on time-based performance and overall firm performance, Journal of Operations Management 22(6): 557-573. http://dx.doi.org/10.1016/j.jom.2004.08.001 
Duffy, R.; Fearne, A. 2004. The impact of supply chain partnerships on supplier performance, International Journal of Logistics Management 15(1): 57-71.

http://dx.doi.org/10.1108/09574090410700239

Fisher, M. L.; Hammond, J. H.; Obermeyer, W. R.; Raman, A. 1994. Making supply meet demand in an uncertain world, Harvard Business Review, 83-93.

Flynn, B.; Huo, B.; Zhao, X. 2010. The Impact of supply chain integration on performance: a contingency and configuration approach, Journal of Operations Management 28: 58-71. http://dx.doi.org/10.1016/j.jom.2009.06.001

Frohlich, M. T. 2002. e-Integration in supply chain: the barriers and performance, Decision Science 33(4): 537-556. http://dx.doi.org/10.1111/j.1540-5915.2002.tb01655.x

Frohlich, M. T.; Westbrook, R. 2001. Arcs of integration: an international study of supply chain strategies, Journal of Operations Management 19(2): 185-200.

http://dx.doi.org/10.1016/S0272-6963(00)00055-3

Germain, R.; Iyer, K. N. S. 2006. The interaction of internal and downstream integration and its association with performance, Journal of Business Logistics 27(2): 29-53. http://dx.doi.org/10.1002/j.2158-1592.2006.tb00216.x

Gimenez, C.; Ventura, E. 2003. Supply chain management as a competitive advance in the Spanish grocery sector, International Journal of Logistics Management 14(1): 77-88. http://dx.doi.org/10.1108/09574090310806558

Gimenez, C.; Ventura, E. 2005. Logistics-production, logisticsmarketing and external integration: their impact on performance, International Journal of Operations \& Production Management 25(1): 20-38.

http://dx.doi.org/10.1108/01443570510572222

Handfield, R. B. 1993. A resource dependence perspective of justin-time purchasing, Journal of Operations Management 11(3): 289-311. http://dx.doi.org/10.1016/0272-6963(93)90005-A

Handfield, R. B.; Nichols, E. L. 1999. Introduction to supply chain management, 183, New-Jersey: prentice Hall.

Homburg, C.; Stock, R. M. 2004. The link between salespeople's job satisfaction and customer satisfaction in a business-tobusiness context: A dyadic analysis, Journal of the Academy of Marketing Science 32(2): 144-158.

Hertz, S. 2001. Dynamics of alliances in highly integrated supply chain networks, International Journal of Logistics 4(2): 237-256. http://dx.doi.org/10.1080/13675560110060009

Humphreys, P. K.; Li, W. L.; Chan, L. Y. 2004. The Impact of supplier development on buyer-supplier performance, Omega 32: 131-143. http://dx.doi.org/10.1016/j.omega.2003.09.016

Jayaram, J.; Kannan, V. R.; Tan, K. C. 2004. Influence of initiators on supply chain value creation, International Journal of Production Research 42(20): 4377-4399. http://dx.doi.org/10.1080/00207540410001716516

Kannan, V. R.; Tan, C. K. 2010. Supply chain integration: cluster analysis of the impact of span of integration, Supply Chain Management: An International Journal 5(3): 207-215.

Kaufmann, L.; Carter, C. 2006. International supply relationships and non-financial performance- a comparison of Us and German practices, Journal of Operations Management 24(5): 653-675. http://dx.doi.org/10.1016/j.jom.2005.07.001
Kim, S. W. 2006. Effects of supply chain management practices, integration and competition capability on performance, Supply Chain Management: An International Journal 11(3): 241-248.

Koufteros, X.; Vonderembse, M.; Jayaram, J. 2005. Internal and external integration for product development: the contingency effects of uncertainty, equivocality, and platform strategy, Decision Sciences 36(1): 97-133. http://dx.doi.org/10.1111/j.1540-5915.2005.00067.x

Kulp, S. C.; Lee, H. L.; Ofek, E. 2004. Manufacturer benefits from information integration with retail customers, Management Science 50(4): 431-444.

http://dx.doi.org/10.1287/mnsc.1030.0182

Lee, W. C.; Kwon, G. W.; Severance, D. 2007. Relationship between supply chain performance and degree of linkage among supplier, internal integration and customer, Supply Chain Management: An International Journal 12(6): 444-452.

Li, G.; Yang, H.; Sun, L.; Sohal, S. A. 2009. The Impact of IT implementation on supply chain integration and performance, International Journal of Production Economics 120: 125-138. http://dx.doi.org/10.1016/j.ijpe.2008.07.017

Li, S.; Ragu-Nathan, B.; Ragu-Nathan, T. S.; Subba Rao, S. 2006. The impact of supply chain management practices on competitive advantage and organizational performance, Omega 34(2): 107-124.

http://dx.doi.org/10.1016/j.omega.2004.08.002

Narasimhan, R.; Das, A. 2001. The impact of purchasing integration and practices on manufacturing performance, Journal of Operations Management 19 (5): 593-609. http://dx.doi.org/10.1016/S0272-6963(01)00055-9

Narasimhan, R.; Jayaram, J. 1998. Causal linkages in supply chain management: an exploratory study of North American manufacturing firms, Decision Sciences 29(3): 579-605. http://dx.doi.org/10.1111/j.1540-5915.1998.tb01355.x

Narasimhan, R.; Kim, S. 2002. Effect of supply chain integration on the relationship between diversification and performance: evidence from Japanese and Korean firms, Journal of Operations Management 20(3): 303-323. http://dx.doi.org/10.1016/S0272-6963(02)00008-6

Pagell, M. 2004. Understanding the factors that enable and inhibit the integration of operations, purchasing and logistics, Journal of Operations Management 22: 459-487. http://dx.doi.org/10.1016/j.jom.2004.05.008

Putzger, I. 1998. All the ducks in a row, World Trade 11(9): 54-60.

Prahinski, C.; Benton, W. C. 2004. Supplier evaluations: communication strategies to improve supplier performance, Journal of Operations Management 22: 39-62.

http://dx.doi.org/10.1016/j.jom.2003.12.005

Prajogo, D.; Olhager, J. 2012. Supply chain integration and performance: the effects of long-term relationships, information technology and sharing, and logistics integration, International Journal of Production Economics 135: 514-522. http://dx.doi.org/10.1016/j.ijpe.2011.09.001

Ragatz, G. L.; Handfield, R. B.; Petersen, K. J. 2002. Benefits associated with supplier integration into new product development under conditions of technology uncertainty, Journal of Business Research 55(5): 389-400.

http://dx.doi.org/10.1016/S0148-2963(00)00158-2 
Ramdas, K.; Spekman, R. E. 2000. Chain or chackles: understanding what drives supply chain performance, Interfaces 30(4): 3-21. http://dx.doi.org/10.1287/inte.30.4.3.11644

Richey, G. R.; Chen, H.; Upreti, R.; Fawcett, S.; Adams, G. F. 2009. The Moderating role of barriers on the relationship between drivers to supply chain integration and firm performance, International Journal of Physical Distribution \& Logistics Management 39(10): 826-840.

http://dx.doi.org/10.1108/09600030911011432

Rosenzweig, E. D.; Roth, A. V.; Dean, Jr. J. W. 2003. The influence of an integration strategy on competitive capabilities and business performance: an exploratory study of consumer products manufacturers, Journal of Operations Management 21(4): 437-456. http://dx.doi.org/10.1016/S0272-6963(03)00037-8

Saeed, K. A.; Malhotra, M. K.; Grover, V. 2005. Examining the impact of interorganizational systems on process efficiency and sourcing leverage in buyer-supplier dyads, Decision Sciences 36(3): 365-396.

http://dx.doi.org/10.1111/j.1540-5414.2005.00077.x

Salvador, F.; Forza, C.; Rungtusanatham, M.; Choi, T. Y. 2001. Supply chain interactions and time-related performances: an operations management perspective, International Journal of Operations \& Production Management 21(4): 461-475. http://dx.doi.org/10.1108/01443570110381372

Schoenherr, T.; Swink, M. 2012. Revisiting the arcs of integration: Cross-validations and extensions, Journal of Operations Management 30(1): 99-115.

http://dx.doi.org/10.1016/j.jom.2011.09.001

Shin, H.; Collier, D. A.; Wilson, D. D. 2000. Supply management orientation and supplier/buyer performance, Journal of $\mathrm{Op}$ erations Management 18: 317-333. http://dx.doi.org/10.1016/S0272-6963(99)00031-5

Stank, T. P.; Keller, S. B.; Closs, D. J. 2001. Performance benefits of supply chain logistical integration, Transportation Journal 41(2/3): 32-46.

Stank, T. P.; Keller, S. B.; Daugherty, P. J. 2001. Supply chain collaboration and logistical service performance, Journal of Business Logistics 22(1): 29-48. http://dx.doi.org/10.1002/j.2158-1592.2001.tb00158.x

Stanley, L. L.; Wisner, J. D. 2001. Service quality along the supply chain: implications for purchasing, Journal of Operations Management 19(3): 287-306. http://dx.doi.org/10.1016/S0272-6963(00)00052-8

Stevens, G. C. 1989. Integrating the supply chain, International Journal of Physical Distribution and Logistics Management 19(8): 3-8. http://dx.doi.org/10.1108/EUM0000000000329
Swafford, P. M.; Ghosh, S.; Murthy, N. 2008. Achieving supply chain agility through IT integration and flexibility, International Journal of Production Economics 116(2): 288-297. http://dx.doi.org/10.1016/j.ijpe.2008.09.002

Swink, M.; Narasimhan, R.; Wang, C. 2007. Managing beyond the factory walls: effects of four types of strategic integration on manufacturing plant performance, Journal of Operations Management 25(1): 148-164. http://dx.doi.org/10.1016/j.jom.2006.02.006

Tan, K. C.; Lyman, S. B.; Wisner, J. D. 2002. Supply chain management: a strategic perspective, International Journal of Operations \& Production Management 22(6): 614-631. http://dx.doi.org/10.1108/01443570210427659

Van der Vaart, T.; van Donk, D. 2008. A Critical review on surveybased research in supply chain integration, International Journal of Production Economics 111(1): 42-55. http://dx.doi.org/10.1016/j.ijpe.2006.10.011

Vickery, S.; Jayaram, J.; Droge, C.; Calantone, R. 2003.The effects of an integrative supply chain strategy on customer service and financial performance: an analysis of direct versus indirect relationships, Journal of Operations Management (21): 523-539. http://dx.doi.org/10.1016/j.jom.2003.02.002

Vijayasarathy, L. R. 2010. Supply integration: an investigation of its multi-dimensionality and relational antecedents, International Journal of Production Economics 124(2): 489-505. http://dx.doi.org/10.1016/j.ijpe.2010.01.010

Wang, E. T.; Tai, J. C.; Wei, H. L. 2006. A virtual integration theory of improved supply-chain performance, Journal of Management Information Systems 23(2): 41-64.

http://dx.doi.org/10.2753/MIS0742-1222230203

Wong, C. Y.; Boonitt, S.; Wong, C. W. Y. 2011. The contingency effects of environmental uncertainty on the relationship between supply chain integration and operational performance, Journal of Operations Management 9(6): 604-615. http://dx.doi.org/10.1016/j.jom.2011.01.003

Zhao, X.; Xie, J.; Zhang, W. J. 2002. The impact of information sharing and order-coordination on supply chain performance, Supply Chain Management: an International Journal 7(1): 24-40. http://dx.doi.org/10.1108/13598540210414364

Zailani, S.; Rajagopal, P. 2005. Supply chain integration and performance: US Versus East Asian companies, Supply Chain Management: an International Journal 10(5): 379-393.

Zhao, X.; Huo, B.; Flynn, B. B.; Yeung, J. 2008. The Impact of power and relationship commitment on the integration between manufacturers and customers in a supply chain, Journal of Operations Management 26(3): 368-388. http://dx.doi.org/10.1016/j.jom.2007.08.002

Nikhat AFSHAN. M.A (Patna University), Research Scholar at IBS, Hyderabad (IFHE University, India). Research interests: supply chain management, operations management, new product development, green supply chain. 